\title{
Full realization of internal mammary artery injury after blunt chest trauma
}

\author{
Künt gögüs travması sonrası iç meme arteri yaralanmasının tam olarak farkına varılması \\ Chen Jinming ${ }^{\circledR}$ ', Yang Guanggen ${ }^{1}$ ', Shen Zhong ${ }^{\circledR}$, Wang Liang $\mathbb{(}^{2}$ \\ Institution where the research was done: \\ Department of Surgery, The Third People's Hospital of Hangzhou, Zhejiang, China \\ Author Affiliations: \\ 'Department of Surgery, The Third People's Hospital of Hangzhou, Zhejiang, China \\ ${ }^{2}$ Department of Thoracic Surgery, Zhejiang University, Zheiang , China
}

\begin{abstract}
Due to the substantial and continual increase in the number of motorized vehicles globally, clinicians are faced with an enormous population at risk for suffering internal mammary artery injuries after blunt chest trauma. Nevertheless, very little attention has been paid to this issue by relevant health practitioners. In addition, there is a scarcity of extant research data, as well as societal guidelines, regarding internal mammary artery injury. In cases with undetected internal mammary artery injury, however, the outcome may be catastrophic or fatal. Thus, investigating and reviewing the anatomy, etiology, diagnostic approaches, and treatment strategies for patients with internal mammary artery injury are urgently needed.
\end{abstract}

Keywords: Blunt chest trauma; diagnosis; internal mammary artery injury; treatment.

With the increasing number of motorized vehicles worldwide, injury to the internal mammary artery (IMA) following blunt chest trauma is much more frequent than previously thought. The first reported case of injury to the IMA was in the $1930 \mathrm{~s} .{ }^{[1]}$ Because clinicians have not paid sufficient attention to IMA injury, many cases have either not been reported or have been published only in non-English extant literature. Moreover, such injuries may often be missed during initial evaluations, because of the presence of only slight signs in the anterior chest wall. However, when an IMA injury is undetected, the consequences tend to be dire due to the associated occurrence of lethal shock in $45-55 \%$ of patients. ${ }^{[2,3]}$

\section{$\ddot{O} Z$}

Tüm dünyada motorlu taşıtların sayısındaki ciddi ve sürekli artış nedeniyle klinisyenler künt göğüs travması sonrası iç meme arteri yaralanması geçirme riski taşıyan büyük bir popülasyonla karşı karşıyadır. Buna rağmen, ilgili sağlık uygulayıcıları tarafından bu konu ile çok az ilgilenilmektedir. Ayrıca, iç meme arteri yaralanması hakkında geçerli çok az araştırma verisi ve toplumsal kılavuz ilkesi bulunmaktadır. Diğer yandan, tespit edilmemiş iç meme arteri yaralanması olan olgularda sonuç yıkıcı veya ölümcül olabilir. Buna bağlı olarak, iç meme arteri yaralanması olan hastalar için anatominin, etyolojinin, tanısal yaklaşımların ve tedavi stratejilerinin araştırılması ve incelenmesi acilen gereklidir.

Anahtar sözcükler: Künt göğüs travması; tanı; iç meme arteri yaralanmasi; tedavi.

\section{ANATOMY}

Internal mammary artery arises from the concavity of the first part of the subclavian artery and immediately passes downwards, forwards and medially. In addition, it lies on the pleura in the upper intercostal spaces up to the third costal cartilage. It then continues anterior to the transversus thoracis muscle to end in the sixth intercostal space by dividing into the superior epigastric and musculophrenic arteries. ${ }^{[4]}$ The left subclavian artery directly derives from the aortic arch, and the right springs from the brachiocephalic trunk. Left IMA diameter has been measured at the second $(2.56 \pm 0.39 \mathrm{~mm})$, third $(2.46 \pm 0.38 \mathrm{~mm})$, fourth

Received: September 22, 2017 Accepted: January 31, 2018

Correspondence: Wang Liang, MD. Department of Thoracic Surgery, Zhejiang University, 310009 Hangzhou, Zheiang, China. Tel: +86-571-87783641 e-mail: 2313069@zju.edu.cn 
$(2.39 \pm 0.38 \mathrm{~mm})$ and fifth $(2.35 \pm 0.38 \mathrm{~mm})$ rib level, respectively. ${ }^{[5]}$ In addition, the right IMA and vein are larger than the left in all intercostal spaces. ${ }^{[6]}$ It is a rare occurrence when a left IMA originates from the distal subclavian artery. ${ }^{[7]}$ The IMA and its accessory branches, in addition to perfusing the chest wall structures, also contribute to supplying the thymus, diaphragm, pericardium, bronchia, female breast and superior abdominal wall, as well as the liver in special circumstances. ${ }^{[8]}$

\section{ETIOLOGY}

Most IMA injuries after blunt chest trauma are caused by a severe impact, such as from a motorcycle or automobile accident, or from participating in a physically dangerous athletic activity, such as American football. ${ }^{\left[{ }^{9]}\right.}$ Rare causes of IMA injury include falling or jumping from a height, pounding of the chest, being struck by a heavy object, suffering from an explosive injury, and performing chest compressions. ${ }^{[10-14]}$ Possible mechanisms of IMA injury include fracture of an adjacent bony structure, such as a rib, clavicle or sternum, or shearing forces acting on the IMA during periods of extreme acceleration or deceleration. ${ }^{[15]}$

\section{CLINICAL PRESENTATIONS}

Both males and females can injure their IMA. The right, left, and bilateral IMAs can be injured by an external force. There is a predominant incidence of IMA injury in males and on the left side. ${ }^{[2]}$ The leading causes of IMA injuries are motorcycle and automobile accidents. ${ }^{[2]}$ Compared to females, more males ride motorcycles and participate in physically strenuous athletic activities, such as American football, rugby, and soccer. In traumatic aortic injuries, the site of rupture is in the region of the isthmus, just distal to the left subclavian artery. ${ }^{[16]}$ A total of $85 \%$ of injured branch vessels directly originate from the aortic arch after blunt thoracic trauma. ${ }^{[17]}$ Therefore, a greater incidence of left IMA injury may be correlated with the different anatomical structure connected with the

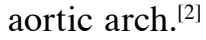

Patients' only complaint with IMA injury is anterior chest pain and chest tightness. ${ }^{[9]} \mathrm{A}$ secondary survey of IMA injury showed breast contusion or abrasion, a small area of subcutaneous emphysema, crepitus in the chest wall, and decreased breathing sounds. Additionally, midsternal tenderness to palpation exists, as well as multiple areas of ecchymosis and prominent swelling in the upper chest. ${ }^{[10,18-20]}$ For patients with traumatic arteriovenous fistula of the IMA, a pulsating mass along the parasternal area where a loud bruit is audible is often present. ${ }^{[21]}$
Some IMA patients are admitted to the hospital with severe shock. Other vital signs, however, are stable on an initial survey of these patients. After a brief period, these patients often suddenly experience shock symptoms. In addition, the average IMA blood flow is $150 \mathrm{~mL} /$ minute, which can result in a lifethreatening hemorrhage within a few minutes. ${ }^{[22]}$ Although IMA transection can sometimes retract and achieve temporary hemostasis during periods of hypotension and arterial spasm, renewed bleeding may occur once the patient is resuscitated. ${ }^{[23]}$

Internal mammary arteries have anterior intercostal, sternal, and perforating branches. ${ }^{[2]}$ Therefore, the different branches of the IMA can be injured by blunt chest trauma. If undiagnosed, IMA injuries may result in persistent bleeding. Portable supine chest radiographs often show a markedly widened mediastinum and obscuration of the aortic knob. ${ }^{[25]}$

Color-coded duplex sonography uses standard ultrasound methods to produce images of blood vessels. In addition, a computer converts Doppler sounds into colors that represent the speed and direction of blood flow through the vessel. In the course of preoperative diagnosis and postoperative follow-up, portable colorcoded duplex sonography is routinely utilized to provide quick assessments of blood vessels for use by clinicians. ${ }^{[26]}$

Contrast enhanced computed tomography (CT) or computed tomography angiography (CTA), when performed urgently, plays a fundamental role in identifying the presence of active bleeding, defining its origin, and thus directing efficacious management of the patient. Meanwhile, multidetector CTA provides a time-efficient method for patients with acute bleeding, leads to faster selective catheterization of bleeding vessels, and thereby facilitates embolization. ${ }^{[27]}$

Magnetic resonance angiography (MRA) is also utilized to generate images of arteries. With recent advancements in hardware and software techniques, MRA provides dramatically improved functionality. For example, rapid whole chest contrast-enhanced MRA using parallel imaging enables scan time to be significantly reduced to only 16 seconds. ${ }^{[28]}$ Moreover, the use of novel intravascular contrast agents substantially increases image windows and decreases contrast dose. ${ }^{[29]}$ The lower risk and cost of noncontrast enhanced MRA has attracted renewed interest in this technique. However, non-contrast enhanced MRA methods still require longer scan times than contrast-enhanced MRA. ${ }^{[28,30]}$ 
Invasive catheter digital subtraction angiography (DSA) has been historically used to image the peripheral artery system, and still remains the optimal choice. However, newer developments in axial imaging, including CTA and MRA, have in large part supplanted DSA for imaging the peripheral artery system in clinical practice. ${ }^{[31]}$ Although CTA screening is more cost effective than DSA, DSA can be applied to achieve not only quick diagnosis, but also prompt treatment. ${ }^{[32]}$ Currently, neither CTA nor MRA constitutes an adequate substitute for DSA.

The aorta is the most common major thoracic artery injured by blunt trauma. Injury to supra-aortic trunks is much less common than injury to the aorta. With the increasing use of thoracic CT to assess blunt chest trauma, this vascular injury is more indirectly detected because of associated bleeding. For IMA injury, the diagnostic findings are anterior mediastinal hematoma $(\mathrm{AMH})$, hemothorax, pseudoaneurysm, extra-pleural hematoma, and arteriovenous fistula. ${ }^{[2]}$ Different parts and the extent of IMA injury, adjacent vein injury, as well as the integrity of the pleura, determine differences in bleeding modality. ${ }^{[2]}$ According to anatomical characteristics, IMA injury is relatively easy to form an AMH from its origin to the third costal cartilage, and an extra-pleural hematoma after the third costal cartilage.

Other diagnostic findings regarding IMA injury include pneumothorax, hemopneumothorax, pulmonary contusion, laceration and consolidation, as well as fractures of the rib, clavicle and sternum, and cardiac tamponade.

A rich potential collateral network exists in the mediastinum and pericardium, which renders injury to the IMA prone to producing mediastinal hematoma, pericardial effusion/tamponade, and hemothorax. ${ }^{[23]}$ In addition, AMH associated with cardiac tamponade is focal, rather than a global compression. Internal mammary artery injury, as well as injury to adjacent veins, such as the left subclavian and innominate veins, internal mammary vein, pulmonary vein and chest wall vein, often lead to an arteriovenous fistula. ${ }^{[13,33-35]}$ Thus, transthoracic echocardiography reveals the presence of a dilated vessel with abnormal continuous blood flow in the intercostal space. ${ }^{[35]}$

\section{TREATMENT}

Traumatic injury to the IMA constitutes a major challenge for clinicians. It is quite difficult to diagnose, and different treatment options exist from which to choose. Thoracotomy was once regarded as the optimal treatment for IMA injury, particularly for those patients presenting with profound shock. ${ }^{[36]}$ Patients with unilateral IMA injury were placed in a contralateral decubitus position at $45^{\circ}$. In general, an anterolateral emergent thoracotomy incision is taken. When a chest exploration is requisite, this incision can be extended to the posterolateral side. The length of the incision is mainly based on whether it is desirable to merge other visceral injuries in the thoracic cavity. Active bleeding of IMA injury was found, and controlled with proximal and distal suture ligation. If the patients present with bilateral IMA injuries as well, or the unilateral IMA injury leads to AMH associated with cardiac tamponade, a median sternotomy explorative incision should be selected. ${ }^{[10,19]}$ In addition, injury to the IMA with massive tension hemothorax requires immediate resuscitative thoracotomy. ${ }^{[37]}$ However, surgical treatment is often regarded as an invasive technique. The first reported case of embolotherapy of an IMA injury is believed to have been in 1982. ${ }^{[38]}$ Selective transcatheter arterial embolization (TAE) of the bilateral IMA did not find tissue necrosis in thoracic trauma patients. ${ }^{[39,40]}$ Chen et al. ${ }^{[2]}$ reviewed articles describing IMA injury after blunt chest trauma in 49 patients. Of the 49 patients studied, 20 underwent embolization, 22 underwent surgical operation, four were managed by clinical observation, and three received undescribed treatment. As complete reports, Chen et al. ${ }^{[2]}$ further analyzed 29 cases of IMA injury in 49 patients. Thirteen $(45 \%)$ of the 29 patients presented with symptoms of shock. Of the 13 patients with shock, six underwent an operation, and seven underwent embolization. Nineteen patients $(65.5 \%)$ presented with $\mathrm{AMH}$, and nine patients (31\%) presented with shock and $\mathrm{AMH}$. Anterior mediastinal hematoma combined with cardiac tamponade was reported in six patients (21\%). Of the six patients studied, four underwent an operation, and two were managed by embolization. Four of these patients also had shock, and two did not. In addition, one of the patients died. Moreover, three $(10.3 \%)$ of the 29 patients died as a result of blunt chest trauma, one had a large $\mathrm{AMH}$, one had coexistence of a severely extensive intracranial injury, and one had a left cerebellar hemorrhage.

The success rates for patients with IMA injury in the embolization group and surgically managed group were $91.6 \%$ and $66.0 \%$, respectively. ${ }^{[23]}$ Although embolotherapy offers an effective, efficient, and safe alternative for IMA injury, approximately half of the patients were previously managed by the conventional surgical method. ${ }^{[23]}$ With the extensive development of interventional techniques and materials, transcatheter endovascular techniques are currently regarded as the first choice for IMA injury. As soon as bleeding 
arteries are identified, emergency embolization is performed using gelatin sponge, polyvinyl alcohol particles, and coils. ${ }^{[4]]}$ Because of the diversified arteriographic presentation of acute hemorrhage, proper selection of the embolic agent constitutes the key to successful hemostasis. ${ }^{[41]}$ The advantages of gelfoam are its availability, low cost, and ease and speed of delivery. However, delayed recanalization is one of its disadvantages. ${ }^{[42]}$ At present, gelfoam is the only commercially available biodegradable embolic material used to treat blunt trauma. However, a novel biodegradable macromolecule material with thrombinloaded alginate-calcium microspheres was prepared using electrostatic droplet techniques, and a special method was developed for hemostatic embolization. ${ }^{[43]}$ Guglielmi detachable coil (DC) (Boston Scientific, Natick, MA, USA) occlusion proved to be a safe and effective therapeutic alternative to surgery in patients with ruptured or unruptured basilar tip aneurysms. ${ }^{[44]}$ The convenience of the Guglielmi DC is that it can be recaptured if it is not suitable for the location of the lesion. Electrolytically, DC offers some advantages over conventional coils because of its controlled deployment, repositioning, and removal. ${ }^{[45]}$ However, DCs are expensive, and endovascular treatment using DCs has low cost-efficacy. ${ }^{[46]}$ To achieve the trapping of arteries, fiber-coated platinum coils are generally preferred over DCs because of the convenience of using thrombogenic characteristics. ${ }^{[47]}$ Moreover, the cost of fiber-coated coils is less than $10 \%$ of that of Guglielmi DCs. A MicroNester coil (Cook Medical, Bloomington, IN, USA) was developed from the Nester coil with a 0.018 -inch microcatheter. The most specific feature of the MicroNester coil is the extended length of $14 \mathrm{~cm} \cdot{ }^{[48]}$ Recently, SMART coils (Penumbra Inc., Alameda, CA, USA) have been developed, which transitions into softness along the length of their coils. ${ }^{[49]}$

Temporary arterial balloon occlusion constitutes an effective and safe alternative for controlling hemorrhages in emergent situations. ${ }^{[50]}$ Despite its benefits, balloon occlusion also presents risks, such as endothelial damage, thrombus formation, tissue ischemia and catheter dislocation, as well as vessel dissection or rupture. ${ }^{[51]}$ Intermittent deflation of the occluded balloon is sometimes required to reduce the risk of tissue ischemia. This technique has also been successfully used perioperatively to reduce intraoperative blood loss and transfusion requirement. ${ }^{[52,53]}$

Urgent endovascular stent-graft placement proved to be safe and effective in restoring the arterial lumen and patency, excluding pseudoaneurysms and controlling bleeding caused by arterial lacerations. ${ }^{[54]}$ The endovascular approach limits the risk of operative damage to surrounding structures and the potential for blood loss. The coated endovascular stent has a smoother inner wall than other endovascular stents, which reduces the incidence of intimal thickening, stenosis, and embolism. ${ }^{[55]}$ The IMA is located in the proximal segment of the subclavian artery, where the vertebral artery, thyrocervical trunk, and costocervical trunk are located. It is necessary to cover the IMA ostium with a coated endovascular stent in order to consider the potential compromise with collateral branches, particularly the vertebral artery. It is essential to evaluate the rest of the supra-aortic trunks and the cerebral primary collateral circulation, and well as to perform a balloon occlusion test of the affected vertebral artery. However, patients who cannot tolerate the vertebral artery sacrifice will not be eligible for covering its ostium. ${ }^{[54,56]}$ A "chimney" procedure has been performed, which involved placement of a Viabahn stent (W.L. Gore, Flagstaff, AZ, USA) in the vertebral artery alongside the subclavian arterial endograft. [57] The technical success rate for chimney stents was $94.3 \%$, and the patency rate was $92 \% .{ }^{[58]}$ This procedure provides a viable alternative for emergency patients who are poor candidates for complex open surgical repair. Therefore, chimney graft use is becoming widely accepted as a particularly useful technique in emergent settings. ${ }^{[59]}$ Accessing site arterial injury, endoleaks, graft migration, stent thrombosis, stent infection, intimal thickening, stenosis, and embolism are common complications following endovascular stent placement. ${ }^{[54,57,60]}$ The risks of placing a stent-graft in the proximal subclavian artery still include ischemia and necrosis of the upper limb, neurolysis, brachial plexus injury, subclavian steal syndrome, and cerebral neurologic complications. ${ }^{[5,56,61]}$ A study with a larger sample size and a longer follow-up period should be performed to further evaluate long-term outcomes.

In brief, for patients with IMA injury, selective TAE or selective TAE combined with temporary endovascular balloon-assisted occlusion has become the optimal treatment choice. In anticipation of an immediate conversion to surgery, surgeons and an operating room should be on continual standby during the TAE. ${ }^{[20]}$ At any stage of the procedure, a simultaneous occlusive balloon can be placed at the proximal subclavian artery to achieve rapid and complete bleeding control, if necessary. ${ }^{[61]}$ For emergency patients with severe shock who cannot tolerate complex open surgery, a chimney graft with concurrent balloon-assisted occlusion will be effective. 
If hospitals do not have an adequate endovascular service, however, conventional open surgery must be immediately implemented. Clinical observation is limited to only a small, unenlarged and wellcircumscribed extra-pleural hematoma with longer history. Even if endovascular intervention or surgical treatment is successful and clinical observation is uneventful, strict monitoring is essential to check for the recurrence of acute blood loss. ${ }^{[10,12,18]}$

A detailed rescue flow chart should be created by a multidisciplinary team. In the case of IMA injury, action should be initiated immediately, according to the flow chart. Close coordination of multidisciplinary teams is also necessary.

In conclusion, blunt chest trauma to the internal mammary artery constitutes an under-recognized entity that is associated with a significant risk of morbidity and mortality. Despite its prevalence and serious consequences, it has not been well-described in the extant literature, and remains a highly challenging problem. It is also difficult to diagnose, and different diagnoses and treatment options are available. Knowledge of potential dangers and indicators is critical to select the optimal and highest-yield modality. Once rapid and early diagnosis is confirmed, immediate treatment according to an emergency response preplan is required to avoid severe hemorrhagic shock and acute cardiac tamponade. In the absence of randomized trials or societal guidelines, rapid and definitive diagnosis and immediate endovascular bleeding control are essential for the successful treatment of patients with internal mammary artery injury after blunt chest trauma. In addition, skilled application of endovascular techniques, aggressive resuscitation, close monitoring, a multidisciplinary team, and a detailed preplan are also highly recommended.

\section{Declaration of conflicting interests}

The authors declared no conflicts of interest with respect to the authorship and/or publication of this article.

\section{Funding}

This work was supported by Zhejiang Provincial Natural Science Foundation (LY17H020005) and Zhejiang Medical Health Research Project (2017KY384).

\section{REFERENCES}

1. Horn H. Bemerkenswerter Fall einer Stichverletzung der Art. mammaria intern. sin. mit grossem mediastinalhamatom. Ausgang in völlige Heilung. Zbl Chir 1930;57:2550.

2. Chen JM, Lv J, Ma K, Yan J. Assessment of internal mammary artery injury after blunt chest trauma: a literature review. J Zhejiang Univ Sci B 2014;15:864-9.
3. Hagiwara S, Ogino T, Morimura M, Yamada T, Furukawa K, Ishihara $\mathrm{K}$, et al. Bilateral internal mammary artery injury without fracture of the chest following a traffic accident. Kitakanto Med J 2010;60:159-62.

4. McVay CB. Anson \& McVay's surgical anatomy. Vol 1, 6th ed. Philadelphia: W. B. Saunders; 1984.

5. Gopal D, Singh NG, Jagadeesh AM, Ture A, Thimmarayappa A. Comparison of left internal mammary artery diameter before and after left stellate ganglion block. Ann Card Anaesth 2013;16:238-42.

6. Cook JA, Tholpady SS, Momeni A, Chu MW. Predictors of internal mammary vessel diameter: A computed tomographic angiography-assisted anatomic analysis. J Plast Reconstr Aesthet Surg 2016;69:1340-8.

7. Uygur R, Akyüz A, Çağlar V, Alpsoy S, Akkoyun DC. Anomalous origin of left internal mammary artery from distal subclavian artery. Turk Gogus Kalp Dama 2014;22:414-5.

8. Sajja LR, Mannam G. Internal thoracic artery: anatomical and biological characteristics revisited. Asian Cardiovasc Thorac Ann 2015;23:88-99.

9. Kwon OY, Chung SP, Yoo IS, Song CJ, Kim IB, Kim SW. Delayed presentation of internal mammary artery rupture after blunt chest trauma: characteristic $\mathrm{CT}$ and plain $\mathrm{x}$ ray findings. Emerg Med J 2005;22:664-5.

10. Nomori H, Ootsuka T, Horio H, Naruke T, Suemasu K. Bilateral internal thoracic artery injury induced by blunt trauma. Jpn J Thorac Cardiovasc Surg 2003;51:214-6.

11. Suh JH, Kim YH. Extra-thoracic hematoma after minor blunt chest injury. Eur J Cardiothorac Surg 2008;33:1140.

12. Braatz T, Mirvis SE, Killeen K, Lightman NI. CT diagnosis of internal mammary artery injury caused by blunt trauma. Clin Radiol 2001;56:120-3.

13. Radanović B, Simunić S, Oberman BB, Jernej B, Tonković I, Kruzić Z. Arteriovenous fistula of the internal mammary artery (combat injury): transcatheter intravascular coil occlusion. Eur Radiol 1996;6:236-8.

14. Kawakami S, Noguchi T, Doi T, Tahara Y, Sanda Y, Fukuda $\mathrm{T}$, et al. Internal Mammary Artery Injury Related to Chest Compressions in a Patient with Post-cardiac Arrest Syndrome. Intern Med 2016;55:1299-303.

15. Husted JW, Stock JR, Manella WJ. Traumatic anterior mediastinal hemorrhage: control by internal mammary artery embolization. Cardiovasc Intervent Radiol 1982;5:268-70.

16. Rittenhouse EA, Dillard DH, Winterscheid LC, Merendino KA. Traumatic rupture of the thoracic aorta: a review of the literature and a report of five cases with attention to special problems in early surgical management. Ann Surg 1969;170:87-100.

17. Chen MY, Regan JD, D'Amore MJ, Routh WD, Meredith JW, Dyer RB. Role of angiography in the detection of aortic branch vessel injury after blunt thoracic trauma. J Trauma 2001;51:1166-71.

18. Patel K, Kimbrell BJ, Marx MV, Petrone P, Asensio JA. Angiographic embolization of an expanding breast hematoma after blunt trauma: a novel approach to a rare injury. J Trauma 2009;67:14-6.

19. Cheng YC, Chen CW, Lee WC, Kuo LC, Lin HL. Retrosternal 
hemomediastinum caused by internal mammary artery injury: a case report and review of the literature. J Emerg Crit Care Med 2010;21:83-7.

20. Kawamura S, Nishimaki H, Takigawa M, Lin ZB, Imai $\mathrm{H}$, Hayakawa $\mathrm{K}$, et al. Internal mammary artery injury after blunt chest trauma treated with transcatheter arterial embolization. J Trauma 2006;61:1536-9.

21. Ishikawa T, Brown GR. Traumatic arteriovenous fistula of the internal mammary artery. J Trauma 1977;17:978-80.

22. Ritter DC, Chang FC. Delayed hemothorax resulting from stab wounds to the internal mammary artery. J Trauma 1995;39:586-9.

23. Whigham CJ Jr, Fisher RG, Goodman CJ, Dodds CA, Trinh CC. Traumatic injury of the internal mammary artery: embolization versus surgical and nonoperative management. Emerg Radiol 2002;9:201-7.

24. Henriquez-Pino JA, Gomes WJ, Prates JC, Buffolo E. Surgical anatomy of the internal thoracic artery. Ann Thorac Surg 1997;64:1041-5.

25. Smith DC, Senac MO, Bailey LL. Embolotherapy of a ruptured internal mammary artery secondary to blunt chest trauma. J Trauma 1982;22:333-5.

26. Kanai M, Sekiguchi H. Avoiding vessel laceration in thoracentesis: a role of vascular ultrasound with color Doppler. Chest 2015;147:5-7.

27. Geffroy Y, Rodallec MH, Boulay-Coletta I, Jullès MC, Ridereau-Zins C, Zins M. Multidetector CT angiography in acute gastrointestinal bleeding: why, when, and how. Radiographics 2011;31:35-46.

28. Hartung MP, Grist TM, François CJ. Magnetic resonance angiography: current status and future directions. J Cardiovasc Magn Reson 2011;13:19.

29. Finn JP, Nguyen KL, Han F, Zhou Z, Salusky I, Ayad I, et al. Cardiovascular MRI with ferumoxytol. Clin Radiol 2016;71:796-806.

30. Biglands JD, Radjenovic A, Ridgway JP. Cardiovascular magnetic resonance physics for clinicians: Part II. J Cardiovasc Magn Reson 2012;14:66.

31. Meyersohn NM, Walker TG, Oliveira GR. Advances in axial imaging of peripheral vascular disease. Curr Cardiol Rep 2015;17:87.

32. Wang AC, Charters MA, Thawani JP, Than KD, Sullivan SE, Graziano GP. Evaluating the use and utility of noninvasive angiography in diagnosing traumatic blunt cerebrovascular injury. J Trauma Acute Care Surg 2012;72:1601-10.

33. Ito T, Sakamoto T, Norio H, Kaji T, Okada Y. An arteriovenous fistula between the internal mammary artery and the pulmonary vein following blunt chest trauma. Cardiovasc Intervent Radiol 2005;28:120-3.

34. Ishikawa T, Brown GR. Traumatic arteriovenous fistula of the internal mammary artery. J Trauma 1977;17:978-80.

35. Nakamura T, Matsumoto M, Ishida T, Shimada Y. Internal mammary arteriovenous fistula treated with transcatheter embolization. Intern Med 2012;51:2351-3.

36. Ritter DC, Chang FC. Delayed hemothorax resulting from stab wounds to the internal mammary artery. J Trauma 1995;39:586-9.
37. Al Hassani A, Abdul Rahman Y, Kanbar A, El-Menyar A, Al-Aieb A, Asim M, et al. Left internal mammary artery injury requiring resuscitative thoracotomy: a case presentation and review of the literature. Case Rep Surg 2012;2012:459841.

38. Smith DC, Senac MO, Bailey LL. Embolotherapy of a ruptured internal mammary artery secondary to blunt chest trauma. J Trauma 1982;22:333-5.

39. Betsch M, Jungbluth P, Grassmann JP, Fürst G, Windolf J, Wild M. Bilateral injuries of the internal mammary artery following blunt thoracic trauma. Unfallchirurg 2010;113:75760.

40. Yeh CC, Hsieh CH, Wang YC, Chung PK, Chen RJ. Concomitant aortic valve and internal mammary artery injuries in blunt chest trauma: report of a case. Surg Today 2009;39:790-4.

41. Wang HL, Xu CY, Wang HH, Xu W. Emergency Transcatheter Arterial Embolization for Acute Renal Hemorrhage. Medicine (Baltimore) 2015;94:1667.

42. Jander HP, Russinovich NA. Transcatheter gelfoam embolization in abdominal, retroperitoneal, and pelvic hemorrhage. Radiology 1980;136:337-44.

43. Rong JJ, Liang M, Xuan FQ, Sun JY, Zhao LJ, Zhen HZ, et al. Alginate-calcium microsphere loaded with thrombin: a new composite biomaterial for hemostatic embolization. Int J Biol Macromol 2015;75:479-88.

44. Vallee JN, Aymard A, Vicaut E, Reis M, Merland JJ. Endovascular treatment of basilar tip aneurysms with Guglielmi detachable coils: predictors of immediate and longterm results with multivariate analysis 6-year experience. Radiology 2003;226:867-79.

45. Wang D, Su L, Han Y, Fan X. Ethanol embolotherapy of high-flow auricular arteriovenous malformations with electrolytically detachable coil-assisted dominant outflow vein occlusion. Eur J Vasc Endovasc Surg 2014;48:576-84.

46. Kim MS. Endovascular coil trapping of a ruptured dissection aneurysm of the vertebral artery using detachable coils and micro-tornado $^{\circledR}$ coils. J Cerebrovasc Endovasc Neurosurg 2013;15:96-101.

47. Jansen O, Dörfler A, Forsting M, Hartmann M, von Kummer R, Tronnier V, et al. Endovascular therapy of arteriovenous fistulae with electrolytically detachable coils. Neuroradiology 1999;41:951-7.

48. Hayashi K, Kitagawa N, Morikawa M, Hiu T, Morofuji Y, Suyama K, et al. MicroNester coil for neurointervention. J Neurosurg 2009;110:40-3.

49. Spiotta AM, Fargen KM, Lena J, Chaudry I, Turner RD, Turk AS, et al. Initial Technical Experience with the SMART Coil for the Embolization of Intracranial Aneurysms. World Neurosurg 2017;97:80-5.

50. Chao SP, Hung HF. Temporary arterial balloon occlusion of internal iliac artery to control hemorrhage after pelvic trauma. Acta Cardiol Sin 2009;25:218-21.

51. DiPasquale T, Greiwe RM, Simmons P, Zweibel B, Bernasek T, Steinberg J, et al. Temporary partial intra-iliac balloon occlusion for the treatment of acetabulum fracture in a Jehovah's Witness: a case report. J Orthop Trauma 2005;19:415-9. 
52. Chou MM, Kung HF, Hwang JI, Chen WC, Tseng JJ. Temporary prophylactic intravascular balloon occlusion of the common iliac arteries before cesarean hysterectomy for controlling operative blood loss in abnormal placentation. Taiwan J Obstet Gynecol 2015;54:493-8.

53. Takahashi S, Okada K, Orihashi K, Sueda T. Arteriooesophageal fistula caused by aberrant right subclavian artery aneurysm. Interact Cardiovasc Thorac Surg 2013;16:920-2.

54. Cohen JE, Rajz G, Gomori JM, Verstandig A, Berlatzky Y, Anner H, et al. Urgent endovascular stent-graft placement for traumatic penetrating subclavian artery injuries. J Neurol Sci 2008;272:151-7.

55. Wang J, Lao J, Liu Y, Zhuo G, Zhang H, Chen L. Case report of emergency repair of injury to the great vessels of the clavicular region by coated endovascular stent implantation. Exp Ther Med 2013;6:61-4.

56. Shang EK, Fairman RM, Foley PJ, Jackson BM. Endovascular treatment of a symptomatic extracranial vertebral artery aneurysm. J Vasc Surg 2013;58:1391-3.
57. Schlösser FJ, Aruny JE, Freiburg CB, Mojibian HR, Sumpio $\mathrm{BE}$, Muhs BE. The chimney procedure is an emergently available endovascular solution for visceral aortic aneurysm rupture. J Vasc Surg 2011;53:1386-90.

58. Zou J, Jiao Y, Zhang X, Jiang J, Yang H, Ma H. Early- and Mid-term Results of the Chimney Technique in the Repair of Aortic Arch Pathologies. Cardiovasc Intervent Radiol 2016;39:1550-6.

50. Hogendoorn W, Schlösser FJ, Moll FL, Sumpio BE, Muhs BE. Thoracic endovascular aortic repair with the chimney graft technique. J Vasc Surg 2013;58:502-11.

60. Taggart NW, Minahan M, Cabalka AK, Cetta F, Usmani K, Ringel RE. Immediate Outcomes of Covered Stent Placement for Treatment or Prevention of Aortic Wall Injury Associated With Coarctation of the Aorta (COAST II). JACC Cardiovasc Interv 2016;9:484-93.

61. Kargiotis O, Siahos S, Safouris A, Feleskouras A, Magoufis G, Tsivgoulis G. Subclavian Steal Syndrome with or without Arterial Stenosis: A Review. J Neuroimaging 2016;26:473-80. 